University of Nebraska - Lincoln

DigitalCommons@University of Nebraska - Lincoln

Journal for the Advancement of Developing

Economies

Economics Department

2013

\title{
Multinational Enterprise Entry Modes in Sub-Saharan Africa: An Eclectic Paradigm Perspective
}

Isaac Yao Addae

Morgan State University, iaddae@tnstate.edu

Martinez Vencia Addae

Florida Institute of Technology

Follow this and additional works at: https://digitalcommons.unl.edu/jade

Part of the Econometrics Commons, Growth and Development Commons, International Economics Commons, Political Economy Commons, Public Economics Commons, and the Regional Economics Commons

Addae, Isaac Yao and Addae, Martinez Vencia, "Multinational Enterprise Entry Modes in Sub-Saharan Africa: An Eclectic Paradigm Perspective" (2013). Journal for the Advancement of Developing Economies. 19.

https://digitalcommons.unl.edu/jade/19

This Article is brought to you for free and open access by the Economics Department at DigitalCommons@University of Nebraska - Lincoln. It has been accepted for inclusion in Journal for the Advancement of Developing Economies by an authorized administrator of DigitalCommons@University of Nebraska - Lincoln. 


\title{
Multinational Enterprise Entry Modes in Sub-Saharan Africa: An Eclectic Paradigm Perspective
}

\author{
Isaac Yao Addae ${ }^{1}$, Martinez Vencia Addae ${ }^{2}$ \\ ${ }^{1}$ Morgan State University \\ ${ }^{2}$ Florida Institute of Technology
}

\begin{abstract}
The use of entry modes by multinational firms has received increased attention from international business scholars. Based on the context of sub-Saharan Africa, this research reviews the locational benefits offered to MNEs by in this region. Borrowing from the eclectic paradigm of international production, the research also examines the effects of each type of entry on the locational advantages offered to MNEs. Propositions are presented to suggest which mode of entry MNEs should pursue in African markets, based on the existence of locational advantages that complement existing firmspecific advantages. Practical and research implications are discussed, in addition to considerations for future research.
\end{abstract}

\section{INTRODUCTION}

Within the current global economy, the internationalization of business activity by way of foreign direct investment (FDI) has occurred at increasing rates, specifically within developing markets (United Nations Conference on Trade and Development [UNCTAD], 2013). FDI is a form of international business activity that provides various benefits to firms. In the case of multinational enterprises (MNEs) or firms operating across multiple nations (Teece, 1985), FDI provides an option for expansion into foreign markets. Internationalization through FDI is guided by market imperfections such as rising labor costs (Calvet, 1981) and enables firms to grow and expand by accessing demand for their products in existing and emerging markets. Multinational firms have utilized international markets to diversify their customer base and product offerings, as well as financial portfolios (Wilkins, 2009). In addition, government entities have even begun to capitalize on the ability to invest assets from state-owned enterprises and sovereign wealth funds into international markets. While it is widely accepted that internationalization is beneficial to firms, international business scholars continue to explore why firms seek to organize in foreign markets, where they choose to organize, and how firms enter these markets (Verbeke and Yuan, 2010).

In addressing the "why" aspect of a firm's decision to internationalize, scholars (Buckley \& Hashai, 2009) have leaned towards the eclectic theory of international production offered by Dunning (1980; see also Dunning 1988/2000/2001). The eclectic theory was initially proposed in an attempt to understand the cause of MNE foreign production. According to the theory, a firm's decision to expand into foreign markets is prompted by the realization that firm-specific advantages (asset, transaction) are of greater value if they are transferred internally across the firm, as opposed to transferred externally in the market (Dunning, 1988). These advantages are utilized in international markets due to the failure of markets that the firm normally operates in. In addition, ownership, 
locational, and internationalization (OLI) advantages influence the decision of MNE foreign market expansion (Dunning, 1980). Also, of concern to the MNE is the ability to develop new firm-specific advantages through involvement in FDI activity (Verbeke, 2009), a factor that weighs into the decision of market selection and engagement. Given the usefulness of the eclectic theory in explaining the "why" aspect of MNE international activity, it is limited in its ability to address "how," or specifically, the various modes of entry utilized by MNEs.

Extant literature in the field of international business highlights the various options or modes of entry available to firms seeking to internationalize (Anderson \& Gatignon, 1986; Hennart, 1988/1989; Pan \& Tse, 2000; Tallman \& Shenkar, 1994). In the first option, MNEs can develop the internal capabilities needed to conduct business in foreign locales and execute transactions using the market-based approach. In addition to pure market transactions, MNEs can acquire a wholly owned subsidiary in the target location. This approach provides MNEs with the benefit of organizational resources and capabilities that can be used to exploit market opportunities, while offsetting the intensive utilization of resources required for internal capability development. Joint ventures or alliances with other firms represent a third mode of entry available to MNEs. This option allows MNEs to form partnerships to achieve their internationalization goals by cooperation across firms. Given these various approaches, the choice of entry mode by MNEs is dependent upon the characteristics of the foreign market that the firm seeks to enter, in addition to the perceived ability of the firm to develop new capabilities and specific advantages.

Relying on insights from research in international business, an understanding can be reached concerning the "why" and "how" aspects of MNE foreign market expansion (see Verkeke, 2009). The next logical step would be to address the decision regarding "where" MNEs choose to internationalize their business activities. The eclectic theory emphasizes the existence of locational advantages as a factor in the choice of market location. Foreign markets are viewed as desirable when locational characteristics and resources complement an MNE's firm-specific advantages (Dunning, 1988). While countries such as India, China, and other emerging markets have received significant FDI (Ernst \& Young, 2012a), other geographic locations may possess locational advantages beneficial to MNEs.

Markets within Africa may serve as a viable alternative for MNE investment, evidenced by data from the African Development Bank that suggests the continent has experienced increases in economic activity and development, resulting in lower poverty levels and a growing middle class (Mubila \& Aissa, 2011). Further evidence of the viability of these markets can be found in a recent report from the UNCTAD (2013), which suggests that FDI flows into African markets have increased despite overall reductions in global FDI activity. The strengthening of the middle class in Africa has led to increased purchasing power, resulting in heightened demand for consumer products. In the eyes of the MNE, the economic improvements observed across the African continent, specifically in the Sub-Saharan region, can translate into markets primed for exploitation. This translation can make this region a potentially ideal location for expansion. For instance, the World Economic Forum's (2012) Global Competitiveness report indicates that the Sub-Saharan region of Africa is positioned to compete in the global economic market, despite identified vulnerabilities.

Although Africa possesses many opportunities for investment, the environmental uncertainty due 
to poor government and regulatory structures poses significant entry challenges for MNEs (Brenton, Cadot, \& Pierola, 2012). To assist firms in the decision-making process related to market selection and entry mode, this research will examine the Sub-Saharan region of Africa to assess the appropriate MNE mode of entry in the region. Examples of MNE FDI activity in South Africa and the West-African nation of Ghana will be highlighted to provide a contextual setting for the discussion; however, the discussion is applicable to the continent as a whole. This research will also build upon the eclectic theory of international production by assessing the locational advantages offered to MNEs within the Sub-Saharan region. Shedding light on the appropriate mode of entry in Africa will benefit MNEs as they seek to expand their international business activity on the continent.

A contribution to the field of international business will be offered by extending the applicability of Dunning's (1980) eclectic theory of international production, specifically in relation to locational advantages, to the study of MNE entry modes within the African continent. While emphasis is placed on the role of locational advantages, it is acknowledged that ownership and internationalization advantages also influence MNE decision-making. However, in an attempt to explain the "where" aspect of MNE investment activity, considering locational advantages is deemed appropriate to explain market selection.

The following discussion will highlight the importance of locational advantages with the eclectic paradigm, and provide an overview of FDI activity within Africa. In addition, an overview of MNE entry modes in the context of Sub-Saharan Africa will be provided. Propositions will be presented, addressing MNE market selection based on locational advantages and mode of entry. Concluding thoughts and implications for future research will also be addressed.

\section{THE ECLECTIC PARADIGM}

The initial focus on the FDI activity of multinational firms can be traced back to 1960 where Stephen Hymer's dissertation introduced the MNE to FDI theory (Dunning \& Rugman, 1985). Since then, various attempts have been made to pinpoint the factors that influence MNE international activity and FDI (Buckley, 1990; Dunning, 2000; Buckley \& Hashai, 2009; Rugman, 2010; Verbeke \& Yuan, 2010). For example, Kiyoshi Kojima's theory regards FDI as the international trade of intermediate products, and that an MNE in possession of intermediate products engages in trade activity with foreign nations to take advantage of available endowments (Buckley, 1991; Dunning, 1988). Robert Aliber's FDI theory focuses on how firms finance their production activities, highlighting the ability of the MNE to dominate foreign markets (Dunning, 1988). In addition, Calvet (1981) addressed the concept of FDI using the paradigm of market imperfection to suggest that the existence of FDI is created by imperfections in the market. He introduced four determinants of FDI: 1) market disequilibrium hypothesis, 2) governmentimposed distortions 3), market structure imperfections and 4) market failure imperfections (Calvet, 1981).

As suggested by Dunning (1988), an appropriate international production theory must consider the factor endowments existing across various countries as a determinant of MNE activity, and the theory must consider market failure as a driving force within international production. The eclectic theory of international production, originally proposed by Dunning in 1976, was proposed in an attempt to characterize the determinants of MNE foreign production. The theory considers three 
specific factors that influence MNE decision-making (ownership, location, internalization), which are correlated with country, industry and firm- specific variables. From Dunning's (1988) perspective, firm-specific advantages and transactional market failure lead to international production in the eclectic theory. In addition, firms must realize that these firm-specific advantages, classified by Dunning (1998) as asset- based and transaction-based, are more beneficial if exchanged internally rather than externally across the international market.

The selection of market location is guided by the nature of value to be derived by the MNE through investment activity. From Dunning's (1998) perspective, four types of investment activity lead to value creation; 1) resource seeking, 2) market seeking, 3) efficiency seeking, and

4) strategic asset seeking. An MNE's choice of investment activity type is prompted by existing ownership and internationalization advantages; the ability of these advantages leads to the creation of value. Citing the influential role of the institutional environment, Dunning and Lundan (2008) suggest that formal and informal aspects of market location dictate the ability of an MNE to derive value from investment activities. While distinguishing between organizational and locational advantages has posed a challenge to researchers (Itaki, 1991; Rugman, 2010), Dunning (2001) viewed locational advantages as those factors specific to a given geographic location that were "non-transferable" (p. 174). Locational advantages consist of "market size, natural resources, aspects of the infrastructure, the education system, governance structure, and other aspects of political and government activity" (Rugman, 2010, p. 3).

The possession of strategic resources (organizational advantages) leading to a competitive advantage may not always offer the same benefit to the firm when transferred across markets (Cuervo-Cazurra, Maloney, \& Manrakhan, 2007). As a result, when seeking international markets, MNEs must focus on combining firm-specific organizational advantages with the locational advantages offered in various geographic locations. Engaging in FDI enables MNEs to utilize and derive benefit from existing firm-specific advantages, and the eventual development of new firmspecific advantages is dependent upon the nature of the MNE's involvement or entry mode in the foreign market (Verbeke, 2009). Considering the emphasis on the development of new firmspecific advantages, the eclectic theory suggests that MNE investment activity should be directed toward markets that possess complementary resource endowments. In keeping with the eclectic theory perspective, the increasing rate of FDI flows into African markets can be viewed as an indicator of attractive resource endowments, leading MNEs to select these markets for international investment. Given the intended contribution of this paper toward the explanation of "where" MNEs choose to internationalize, linking the locational advantages factor of the eclectic theory to the African context is useful to advance the existing knowledge of international market selection as well as the choice of entry mode during the implementation of MNE FDI strategy.

\section{FDI AND THE AFRICAN CONTEXT}

Given the numerous foreign investment opportunities across the globe, why should MNEs consider investment in Africa? Compared to other regions, countries across Africa are experiencing unprecedented growth (World Economic Forum, 2012). During the late 1990s, a trend of positive growth was observed across the continent of Africa (Berthelemy \& Soderling, 2002). Since the start of the 21st century, and even during the global economic recession, Africa experienced overall growth (Chironga, Leke, Lund, \& van Wamelen, 2011). The McKinsey Global Institute (McKinsey, 
2012a) suggests that from 2000 to 2010, GDP growth in Africa (5.1\%) as a region was only second to the emerging markets of Asia (8.6\%).

In addition to economic growth, levels of FDI across Africa have also been on the rise. While the continent currently receives a marginal rate, or 5.5\%, of global FDI, the flow of FDI into Africa increased by 27\% between 2010 and 2011 (Ernst \& Young, 2012b). From 2000 to 2008, FDI flows into Africa grew nearly $700 \%$ ( $\$ 9$ billion to $\$ 62$ billion), maintaining the highest rates of return across the globe (McKinsey, 2010b). Leading African investment is China, one of the largest contributors to FDI, and has engaged in large infrastructure development projects and increased trade on the continent (Christensen, 2010). However, the flow of FDI originating from nations within the continent has also been on the rise, evidenced by the growing percentage of total FDI attributed to African countries (Ernst \& Young, 2012a).

Within Sub-Saharan Africa, trends of growth are also prevalent. Research suggests that the region contains several emerging markets, in addition to an evolving consumer base (McKinsey, 2010a \& 2012b). Anchored by South Africa, the region boasts numerous countries with improving economic and political climates. In contrast to nations in North Africa, Sub-Saharan nations maintain relatively stable political environments and have experienced gains in GDP and competitiveness (World Economic Forum, 2012). These are positive attributes that make the region attractive, especially considering that foreign investors view stability in economic and political systems as critical factors for business engagement within Africa (Kehl, 2007).

Even though various African countries are viewed as developing nations (Kehl, 2007; McKinsey, $2010 \mathrm{~b}$ ), there are examples of nations that could support MNE activity. For example, a recent report on the business climate of the Economic Community of West African States (ECOWAS) highlighted the ease in which business is conducted across the region (World Bank, 2013). This report, commissioned by the World Bank and the International Finance Corporation, ranked the West-African nation of Ghana highest among ECOWAS nations in terms of the overall climate and ease of business engagement. From a global perspective, Ghana's rank increased from 114 to 103 in terms of global competitiveness due to the relative strength of institutions and improved market efficiency (World Economic Forum, 2012).

Lauded for its political stability and democratic transparency, relative to other African nations, Ghana has been the recipient of increased attention from foreign governments and multinational firms. In 2009, during the first term of U. S. President Barack Obama, Ghana was selected as the destination for the president's first official state visit to the continent (Slack, 2012). Support for the notion of increased MNE interest in Ghana can be found in the recent growth of Diageo Plc., a UKbased beverage company. In 2012 Diageo's Ghanaian subsidiary, Guinness Ghana Breweries Ltd., experienced a twenty-seven percent increase in sales revenue (Dzawu, 2012), suggesting heightened demand from consumers. The recent progression of markets in Sub- Saharan Africa, such as Ghana, may lend credibility to the region from the perspective of MNEs seeking to identify new markets for future investment activities.

\section{MNE MODES OF ENTRY IN SUB-SAHARAN AFRICA}

The continent of Africa has been the recipient of vast amounts of foreign aid and assistance, receiving trillions of dollars over the past several decades (Moyo, 2009a). Although foreign aid has 
been found to have negative effects on private investment in developing countries (Herzer \& Grimm, 2012; Selaya \& Sunesen, 2012), FDI has been identified as a method for African nations to reduce their dependence on foreign aid (Moyo, 2009b). Economic growth and improvement in the developing nations of Africa has been largely linked to the activities of small and medium enterprises (Abor and Quartey, 2010). However, through engaging in investment activity, MNEs can also assist in the development of the continent, given the fact that MNE activity has been found to improve domestic environments (Ayyagari \& Kosová, 2010).

Due to the attractiveness and potential for growth in this region, MNEs seeking to increase foreign investment activity can look towards Sub-Saharan Africa as a viable alternative to other geographic locations. However, due to the diverse nature of the region, each country presents a unique set of opportunities and challenges to MNEs. Investment activity in one country may not yield equal results in another country, given the differences across government and financial institutions, as well as infrastructure and other environmental factors. As a result, MNEs seeking to engage the region should determine the appropriate mode of entry that will increase the ability to achieve desired market performance. The view presented in this research focuses on locational advantages, suggesting that entry mode will be influenced by the complementarity of locational advantages and firm-specific advantages.

\section{Market-Based Approach}

MNEs may decide to pursue the market-based approach if the location lacks suitable alliance partners or existing business operations with sufficient capacity and expertise. Through Greenfield ventures, MNEs may select the market-based approach to establish a new base of operations in locations offering a sense of stability and maintaining supportive infrastructure that complement existing firm-specific advantages. While the economic climate of the Sub-Saharan region is characterized by rapid growth, some nations have progressed at slower rates. In these nations, overall development may still be below the standards deemed appropriate for potential MNE investment. However, the market-based approach may still be suitable in such environments. From the perspective of locational advantages, MNEs may use the lack of development and stable infrastructure as a business opportunity.

Using the market-based approach, Cummins, Inc., an American manufacturing conglomerate, expanded its presence in Ghana through its power generation division (Khan, 2010). Capitalizing on the energy needs of Ghana and surrounding nations, the firm established new operations focused on the distribution power generation technology to businesses and consumers. Given the energy challenges faced by Ghana and other nations across the Sub-Saharan region, prolonged power outages have become commonplace (Brew-Hammond \& Kemausuor, 2007, 2009; Da Costa, 2012). Recognizing the need for alternate sources of power may have been a factor in Cummins' decision to expand into the Ghanaian market, as the market need for power may have served as a locational advantage. In lieu of forming an alliance, or acquiring an existing operation, Cummins opted to utilize experience gained in other international locales to gain a share of the West African market. Moreover, their use of the market-based approach suggests that this method of entry was deemed more appropriate for the use and development of existing and new firm-specific advantages. 


\section{Wholly Owned Subsidiary}

While the alliance mode of entry may appear to be a viable option, some MNEs may opt to acquire existing business operations, resulting in a wholly owned subsidiary. This approach is an equitybased entry mode that provides a high level of control to the parent firm and involves either the acquisition of existing operations or the development of operations from the ground up (Anderson \& Gatignon, 1986; Pan \& Tse, 2000). The use of this approach may stem from incompatible or nonexistent alliance partners currently operating in the market. A wholly owned subsidiary offers the MNE a permanent presence in the target market and does not require the negotiation of contracts with potential alliance partners. In the Sub-Saharan region, despite the rapid economic growth, there are relatively low numbers of established firms that MNEs would seek to engage in alliance partnerships. However, as advances in infrastructure and economic development have improved the business climate (World Economic Forum, 2012), MNEs may be able to identify existing firms suitable for acquisition, especially as the number of Africa- based MNEs continues to grow (Mthembu-Salter, 2012).

Wal-Mart benefitted from locational advantages by acquiring an existing enterprise that successfully penetrated multiple markets across the continent. Combining its knowledge and expertise in the global retail industry with Massmart's existing retail facilities, brand recognition, and consumer base, enabled Wal-Mart to achieve its goal of gaining exposure to African markets. In addition, due to the burgeoning middle class across the Sub-Saharan region (Mubila \& Aissa, 2011) and the anticipated spike in demand for consumer products (McKinsey, 2012b), Wal-Mart's decision to enter Africa may have been influenced by expected revenues stemming from Africa's growth prospects.

\section{Alliances/Joint Ventures/Partnerships}

In situations where subsidiary establishment through acquisition is not desirable, MNEs can mitigate this challenge by partnering with entities that have experience in conducting business within this region through the formation of an alliance. This approach will allow MNEs to combine their resources and expertise with organizations that have a history of operating in Africa. A recent partnership agreement between IBM and Bharti Airtel is an example of this approach (Moeller \& Sharma, 2010). By partnering with Bharti Airtel, an India-based firm with vast experience in Africa's mobile telecommunication industry, IBM was able to increase its involvement on the continent and grow sales in an expanding industry.

International business scholars have primarily focused on the use of international joint ventures and alliances as MNE modes of entry (Buckley, 2002). Joint ventures between firms exist in various types. The international corporate venture is a mode of entry shared between MNEs that can either be equity-based or non-equity based

(Hennart, 1988). According to Hennart (1988), equity joint ventures are formed when "two or more sponsors bring given assets to an independent legal entity and are paid for some or all of their contribution from the profits earned by the entity, or when a firm acquires partial ownership of another firm" (p. 361). This type of venture leads to the creation of a new organization, with equity being shared by partner firms (Pan \& Tse, 2000). In contrast, contractual joint ventures are non- 
equity agreements, allowing the firms involved to minimize risk exposure (Anderson \& Gatignon, 1986; Hennart, 1989; Pan \& Tse, 2000).

Most recently, scholars have directed their focus towards the alliance mode of entry, highlighting partnerships between private firms (business-to-business or B2B), and between private firms and non-governmental organizations (business-to-NGO or B2N) for the purposes of internationalization (Rivera-Santos \& Rufín, 2010; Webb, Kistruck, Ireland, \& Ketchen, 2010). Alliances benefit participating firms by providing access to critical resources (i.e. knowledge, skills, technology), and the success of the alliance is contingent upon the unique contributions of each firm to the partnership (Hamel, Doz, \& Prahalad, 1989).

By incorporating the eclectic theory of international production with the use of alliances and joint ventures in the context of Sub-Saharan Africa, one could suggest that combining locational advantages with the firm-specific advantages possessed by alliance partners will allow for the development of new firm-specific advantages beneficial to the alliance. According to Verbeke (2009), alliances "allow firms to share risks and costs, they allow firms to benefit from their partner's complementary resources, and they allow the quicker development of capabilities to deliver products and services valued by the output market" (p. 309). This mode of entry is advantageous to MNEs due to access to valuable knowledge and capabilities (Inkpen, 2009; Inkpen \& Beamish, 1997; Simon \& Lane, 2004). As MNEs engage in business activity within the Sub-Saharan region, gaining access to the knowledge and capabilities of partner firms can help to reduce the uncertainties faced by operating in this environment.

The Jubilee Joint Venture serves as an example of multiple entities forming an alliance to engage in FDI activity. Led by Tullow Oil, a UK-based MNE engaged in the production and exploration of natural resources, the Jubilee Joint Venture was formed to oversee the collection of oil found in reserves off the Ghanaian coast. The initial alliance was formed to exploit oil deposits discovered in 2007. The initial membership included the Ghana-based subsidiaries of several oil and gas MNEs (Tullow Oil, Kosmos Energy, Anadarko Petroleum Company, Sabre Oil and Gas), a privately-held Ghanaian firm (EO Group), and the state-owned Ghana National Petroleum Company (Tullow Oil Plc., 2012). The mere discovery of oil in Ghana likely provided the locational advantage necessary to prompt the engagement of each MNE in the alliance venture. With each MNE specializing in the extraction and subsequent production of natural resources, their unique expertise and experience fully complemented the identified locational resources. Their engagement in the alliance venture would provide the opportunity to develop additional firm-specific advantages through collaboration with alliance members.

To the extent that market locational advantages complement existing firm-specific advantages, the choice of entry mode will be contingent upon the relative benefits offered to the MNE by these factors. In markets that possess existing firms with mutually beneficial firm-specific advantages, the MNE may select the alliance mode of entry to combine their strengths with those of the identified partner. However, in markets where existing firms may not complement the strengths of MNEs, the choice to establish a wholly owned subsidiary through acquisition may prove beneficial. In markets that lack potential alliance partners or existing firms with useful capabilities, the MNE may choose the market-based approach to enter the market. The following propositions specify the suggested relationships: 
Proposition 1: The relationship between the decision to expand into a new market, and the selected mode of entry, will be mediated by the selection of market location.

Proposition 2: The locational advantages offered within a geographic market will moderate the relationship between the decision to expand into a new market, and the subsequent market selection, in that the nature of the locational advantages will influence the selection of markets.

Proposition 3: The locational advantages offered within a geographic market will moderate the relationship between the choice of market selection and the selected mode of entry, in that the nature of the locational advantages will influence the selection of entry mode.

Based on the prior discussion, it is suggested that the locational advantages of geographic markets will influence the decision-making process of MNEs in relation to market selection and entry mode (see Figure 1). When seeking to internationalize, the process begins with the MNE's decision to expand into new markets. Once this decision is made, the MNE then decides which market location to enter, followed by the desired mode of entry into the selected market. The locational advantages of each market under consideration influence the market selection and entry mode decisions.

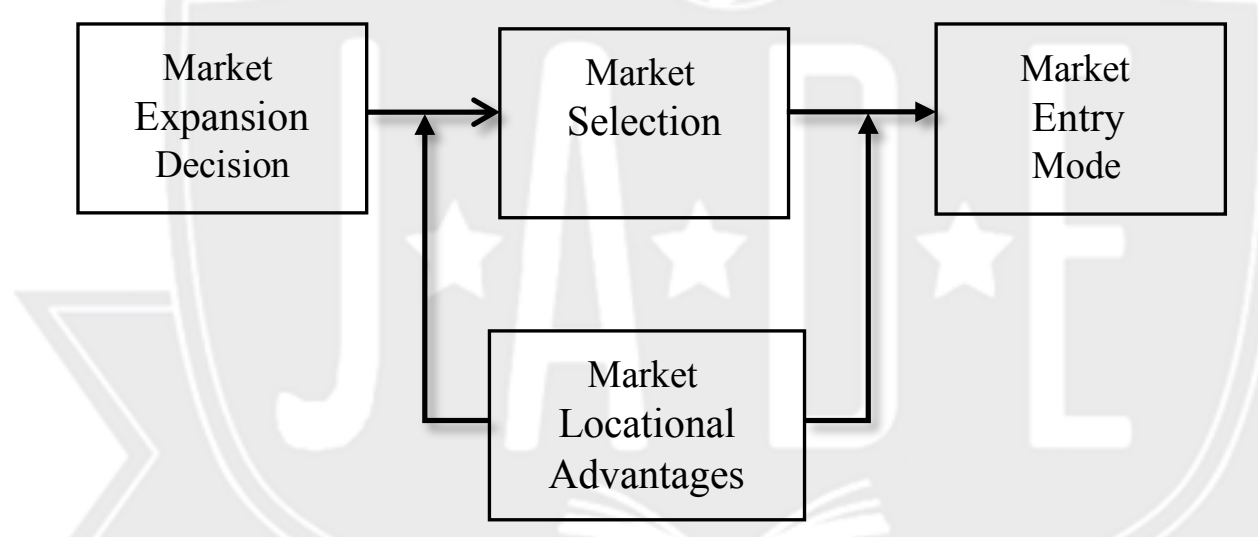

Figure 1: MNE Decision Process for Market Expansion

\section{DISCUSSION}

In general, the context of Africa could benefit from additional research from international business scholars, specifically directed toward improving the current understanding of MNE engagement within the continent. This research sought to contribute to research on Africa through the lens of the eclectic theory and FDI. While it has been acknowledged that limitations exist within the eclectic theory (Dunning, 1988), this research contributes to the field of international business by extending the applicability of Dunning's (1980) eclectic theory of international production to the study of MNE entry modes in the African continent. As scholarly interest in African continues to grow, this research will also provide support for the use of specific entry modes based on countryspecific locational advantages.

The growth of FDI from multinational firms based outside of Africa has been viewed as the primary driver of investment activity on the continent. However, growth in FDI activity from firms based 
within the continent has also increased, with many Africa-based firms engaging in business across the continent (Norbrook, 2012). Based on findings from prior research, FDI can benefit the development and growth of domestic firms due to spillover effects (Ayyagari \& Kosová, 2010), as well as support the economic growth of nations receiving FDI. As MNEs increase their engagement within Africa, the region may also experience improvements. However, the attraction of FDI beneficial to the development of the region is only possible through the improvement of infrastructure and the creation of a transparent business climate devoid of corruption (United Nations Economic Commission for Africa [UNECA], 2005).

Infrastructure, availability of financing, and the level of education across the workforce were found to impact the growth of firms in Africa (Goedhuys \& Sleuwaegen, 2010), leading to the need for continued development in these areas. The tendency for many African countries is to invest a significant portion of national funds into education in order to (Easterly \& Nyarko, 2008) create a labor force with at least a basic level of education. Also, there is a high demand for consumer products due to increases in household spending power (Chironga, Leke, Lund, \& van Wamelen, 2011). Based on these characteristics, markets in the developing nations of Africa can provide various benefits to multinational firms including growth through new streams of revenue, cost reductions due to cheaper labor costs, and opportunities to test product innovations (Prahalad \& Hammond, 2002).

\section{IMPLICATIONS, LIMITATIONS, AND FUTURE RESEARCH}

The discussion presented in this research has multiple practical implications. From an MNE perspective, this research provides a framework useful for understanding the impact of locational advantages on the decision-making processes of firm leaders. By moving beyond the decision to select new markets arbitrarily, this research suggests that the decision to internationalize should depend on the ability to combine existing firm-specific advantages with locational advantages. Moreover, the decision to internationalize is suggested to depend on the ability to gain new firmspecific advantages through FDI activity in new markets. Although the eclectic theory highlights the role of ownership and internationalization advantages in FDI activity, the perspective presented in this research considers that these advantages influence the decision to internationalize, but the locational advantages exert a greater influence on market selection and entry mode. In regard to the African context, this research presents an approach to decision-making focused on the selection of markets and MNE entry mode based on locational advantages.

With respect to limitations, the focus of this research was placed on the locational advantage's aspects of the eclectic theory. A discussion on locational advantages is presented as a factor influencing MNE mode of entry. However, the eclectic theory gives consideration to two additional factors that influence MNE decision-making: ownership and internationalization advantages. While the emphasis of this research was directed towards the benefits offered from the perspective of geographic location, future research could explore the influence of ownership and internationalization advantages on MNE modes of entry in Sub-Saharan Africa. This research is also limited by its conceptual focus on MNE activity within Africa. Future research on this subject could empirically examine the relationships identified in the offered propositions. Using country-level data contained in the World Economic Forum Global Competitiveness report, the various longitudinal indicators can be used to assess the influence of market locational advantages on MNE investment activity in the region over a period of time. 


\section{CONCLUSIONS}

This research highlighted the eclectic theory of international production in the context of SubSaharan Africa for the purposes of determining why MNEs may pursue certain modes of entry in this context. The recent growth experienced within the Sub-Saharan region of Africa places it as a prime target for MNE investment. Given that market attractiveness is assessed by MNEs through the availability of locational advantages, the overall development of the region presents an opportunity for MNE investment. Shedding light on the appropriate mode of entry for each African country will benefit MNEs as they seek to expand their international business activity on the continent. The identification of locational advantages that complement firm-specific advantages can assist MNEs in their quest to identify new markets to enter.

\section{REFERENCES}

Abor, J., \& Quartey, P. (2010). Issues in SME development in Ghana and South Africa. International Research Journal of Finance and Economics, 39: 218-228.

Africa Finance Corporation. (2011a). Africa Infrastructure Review, 3rd Quarter, 2011. Africa Finance Corporation. (2011b). Annual Report: Powering Infrastructure Investment,

December 2011. Retrieved from the Africa Finance Corporation website: http://www.africafc.org/

Anderson, E., \& Gatignon, H. (1986). Modes of foreign entry: A transaction cost analysis and propositions. Journal of International Business Studies, 17(3): 1-26.

Ayyagari, M., \& Kosová, R. (2010). Does FDI facilitate domestic entry? Evidence from the Czech Republic. Review of International Economics, 18(1): 14-29.

Berthelemy, J-C., \& Soderling, L. (2002). Will there be emerging-market economies in Africa by the year 2020? IMF Working Paper 02/131. Washington, D.C.: International Monetary Fund. Retrieved from the IMF website: http://imf.org/external/pubs/ft/wp/2002/wp02131.pdf.

Brenton, P., Cadot, O., \& Pierola, M. D. (2012). Pathways to African Export Sustainability. Washington, DC: World Bank. DOI: 10.1596/978-0-8213-9559-2. License: Creative Commons Attribution CC BY 3.0.

Brew-Hammond, A., \& Kemausuor, F. (2007). Energy Crisis in Ghana: Technology, Drought or Policy. Kumasi: Kwame Nkrumah University of Science and Technology.

Brew-Hammond, A., \& Kemausuor, F. (2009). Energy for all in Africa - to be or not to be?! Current Opinion in Environmental Sustainability, 1(1): 83-88.

Buckley, P. J. (1990). Problems and developments in the core theory of international business. Journal of International Business Studies, 21(4): 657-665.

Buckley, P. J. (1991). Kojima's theory of Japanese foreign direct investment revisited. Hitotsubashi Journal of Economics, 32(2), 103-109.

Buckley, P. J. (2002). Is the international business research agenda running out of steam? Journal of International Business Studies, 33(2): 365-373.

Buckley, P. J., \& Hashai, N. (2009). Formalizing internationalization in the eclectic paradigm. Journal of International Business Studies, 40: 58-70.

Calvet, A. (1981). A synthesis of foreign direct investment theories and theories of the multinational firm. Journal of International Business Studies, 12(1): 43-59. 
Chironga, M., Leke, A., Lund, S., \& van Wamelen, A. (2011). Cracking the next growth market: Africa. Harvard Business Review, May 2011.

Christensen, B. V. (2010). China in Africa: A macroeconomic perspective. CGD Working Paper 230. Washington, D.C.: Center for Global Development. Retrieved from the CDG website: http://www.cgdev.org/content/publications/detail/1424567.

Cuervo-Cazurra, A., Maloney, M. M., \& Manrakhan, S. (2007). Causes of the difficulties in internationalization. Journal of International Business Studies, 38(5): 709-725.

Da Costa, K. (2012). Ghana's Energy Crisis Bites Harder, to Persist Till 2013. AllAfrica.com. Retrieved from the AllAfrica.com website: http://allafrica.com/stories/201210030698.html

Dunning, J. H. (1980). Toward an eclectic theory of international production: Some empirical tests. Journal of International Business Studies, 11(1): 9-31.

Dunning, J. H. (1988). The eclectic paradigm of international production: A restatement and some possible extensions. Journal of International Business Studies, 19(1): 1-31.

Dunning, J. H. (2000). The eclectic paradigm as an envelope for economic and business theories of MNE activity. International Business Review, 9(2): 163-190.

Dunning, J. H. (2001). The eclectic (OLI) paradigm of international production: Past, present and future. International Journal of the Economics of Business, 8(2): 173190.

Dunning, J. H., \& Lundan, S. M. (2008). Institutions and the OLI paradigm of the multinational enterprise. Asia Pacific Journal of Management, 25(4), 573-593.

Dunning, J. H., \& Rugman, A. M. (1985). The influence of Hymer's dissertation on the theory of foreign direct investment. The American Economic Review, 75(2), 228-232.

Dzawu, M. M. (2012). Diageo's Ghana Unit to See 27\% Revenue Growth in 2012, SIC Says. Bloomberg. Retrieved from the Bloomberg website http://www.bloomberg.com/news/201204-03/diageo-s-ghana-unit-to-see-27revenue- growth-in-2012-sic-says.html.

Easterly, W., \& Nyarko, Y. (2008). Is the brain drain good for Africa? Brookings Global Economy and Development Working Paper, 19.

Ernst \& Young. (2012a). Building bridges: 2012 Africa attractiveness survey. Retrieved from the Ernst \& Young website: http://www.ey.com/ZA/en/Issues/Businessenvironment/2012Africa-attractiveness- survey.

Ernst \& Young. (2012b). Africa by numbers: Assessing market attractiveness in Africa. Retrieved from the Ernst \& Young website: http://www.ey.com/ZA/en/Issues/Businessenvironment/Africa-by-numbers---mainpage.

Goedhuys, M., \& Sleuwaegen, L. (2010). High-growth entrepreneurial firms in Africa: A quantile regression approach. Small Business Economics, 34(1): 31-51.

Hame, G., Doz, Y. L., \& Prahalad, C. K. (1989). Collaborate with your competitors - and win. Harvard Business Review, 67(1): 133-139.

Hennart, J-F. (1988). A transaction costs theory of equity joint ventures. Strategic Management Journal, 9(4): 361-374.

Hennart, J-F. (1989). Can the "New Forms of Investment" substitute for the "Old Forms?" A transaction costs perspective. Journal of International Business Studies, 20(2): 211-234.

Herzer, D., \& Grimm, M. (2012). Does foreign aid increase private investment? Evidence from panel cointegration. Applied Economics, 44(20): 2537-2550.

Inkpen, A. C. (2009). Strategic Alliances. In A. M. Rugman \& T. L. Brewer (Eds.), The Oxford Handbook of International Business (pp. 402-427). Oxford, UK: Oxford University Press.

Inkpen, A. C., \& Beamish, P. W. (1997). Knowledge, bargaining power, and the instability of international joint ventures. Academy of Management Review, 22(1), 177-202. 
Itaki, M. (1991). A critical assessment of the Eclectic Theory of the MNE. Journal of International Business Studies, 22(3): 445-460.

Khan, N. (2010). Launch of Cummins Ghana facility in Africa. Cummins Power Blog, October 27, 2010. Retrieved from the Cummins Power website: http://cumminspowerblog.com

Kehl, J. R. (2007). Emerging markets in Africa. African Journal of Political Science and International Relations, 1(1): 1-8.

Maylie, D. (2012). Wal-Mart, Massmart Merger Approved in South Africa. Wall Street Journal, March 9, 2012.

http://online.wsj.com/article/SB10001424052970204603004577270942176432300.ht ml.

McKinsey, (2010a). McKinsey on Africa: A continent on the move. McKinsey on Society, July 2010. Retrieved from the McKinsey website: http://mckinseyonsociety.com/mckinsey- onafrica/.

McKinsey, (2010b). Lions on the move: The progress and potential of African economies.

McKinsey Global Institute, June 2010. Retrieved from the MGI website: http://mckinsey.com/insights/mgi.

McKinsey, (2012a). Africa at work: Job creation and inclusive growth. McKinsey Global Institute, August 2012. Retrieved from the MGI Website http://mckinsey.com/insights/mgi.

McKinsey, (2012b). The rise of the African consumer. McKinsey's Africa Consumer Insights Center, October 2012. Retrieved from the McKinsey website: http://csi.mckinsey.com/.

Moeller, M., \& Sharma, A. (2010). Bharti Airtel and IBM Join Forces to Transform Emerging African Mobile Communications Market and Fuel Economic Development Across the Continent. Retrieved from the IBM website: http://www03.ibm.com/press/us/en/pressrelease/32505.wss\#contact.

Moyo, D. (2009a). Why Foreign Aid is Hurting Africa. Wall Street Journal, March 21, 2009. Retrieved from the Wall Street Journal website: http://online.wsj.com/article/SB123758895999200083.html.

Moyo, D. (2009b). Dead Aid: Why Aid is Not Working and How There is Another Way for Africa. London, UK: The Penguin Group.

Mthembu-Salter, G. (2012). Country focus: South Africa in Africa. The Africa Report, 46, 53-56. December 2012 - January 2013.

Mubila, M., \& Aissa, M. B. (2011). The middle of the pyramid: Dynamics of the middle class in Africa. African Development Bank Market Brief. Retrieved from the African Development Bank website: http://www.afdb.org/en/documents/

Norbrook, N. (2012). A sweet spot in global demand. The Africa Report, 46, 67-70. December 2012 - January 2013.

Pan, Y., \& Tse, D. K. (2000). The hierarchical model of market entry modes. Journal of International Business Studies, 31(4): 535-554.

Prahalad, C. K., \& Hammond, A. (2002). Serving the world's poor, profitably. Harvard Business Review, 80(9): 48-59.

Rivera-Santos, M., \& Rufín, C. (2010). Odd couples: Understanding the governance of FirmNGO alliances. Journal of Business Ethics, 94(1): 55-70.

Rugman, A. M. (2010). Reconciling internationalization theory and the Eclectic Paradigm. Multinational Business Review, 18(2): 1-12.

Selaya, P., \& Sunesen, E. R. (2012). Does foreign aid increase foreign direct investment? World Development, 40(11): 2155-2176. 
Sirmon, D., \& Lane, P. (2004). A model of cultural differences and international alliance performance. Journal of International Business Studies, 35(4): 306-319.

Slack, M. (2012). President Obama's Trip to Ghana. Retrieved from The White House website: http://www.whitehouse.gov/blog/2012/06/14/archives-president-obamastrip-ghana.

Tallman, S. B., \& Shenkar, O. (1994). A managerial decision model of international cooperative venture formation. Journal of International Business Studies, 25(1): 91113.

Teece, D. J. (1985). Multinational enterprise, internal governance, and industrial organization. The American Economic Review, 75(2): 233-238.

Tullow Oil Plc. (2012). Jubilee Field Environmental Impact Assessment. Tullow Ghana Limited Environmental Resources Management. Retrieved from the Tullow Oil website: http://www.tullowoil.com/files/pdf/Jubilee Field EIA Chapter 1 25Nov09.pdf

United Nations Economic Commission for Africa (UNECA). (2005). Youth unemployment and regional insecurity in West Africa, December 2005. Retrieved from the UNECA website: http://www.uneca.org/itca/youth/Documents/unemploymentinsecurity\%5B1\%5D.pdf

United Nations Conference on Trade and Development (UNCTAD). (2013). World Investment Report 2013 - Global Value Chains: Investment and Trade for Development. Retrieved from the UNCTAD website: http://www.unctad.org/wir

Verbeke, A. (2009). International Business Strategy. Cambridge, UK: Cambridge University Press.

Verbeke, A., \& Yuan, W. (2010). A strategic management analysis of ownership advantages in the eclectic paradigm. Multinational Business Review, 18(2): 89-107.

Webb, J. W., Kistruck, G. M., Ireland, D., \& Ketchen, D. J. (2010). The entrepreneurship process in base of the pyramid markets: The case of multinational enterprise nongovernment organization alliances. Entrepreneurship Theory \& Practice, 34(3): 555- 581.

Wilkins, M. (2009). The history of Multinational Enterprise. In A. M. Rugman (Ed.), The Oxford Handbook of International Business (pp. 3-38). Oxford, UK: Oxford University Press.

World Bank. (2013). Doing Business 2013: Smarter Regulations for Small and Medium-Size Enterprises. Washington, DC: World Bank Group. DOI: 10.1596/978-0-8213-9615-5. License: Creative Commons Attribution CC BY 3.0

World Economic Forum. (2012). The Global Competitiveness Report 2012-2013. Retrieved from the World Economic Forum website: http://www.weforum.org/reports. 